\title{
Pengembangan Sumber Belajar Matematika Berbentuk Slideshow Interaktif
}

\author{
Varetha Lisarani \\ Sekolah Tinggi Agama Katolik Negeri Pontianak \\ betzyvarethalisarani@gmail.com
}

\begin{tabular}{|c|c|}
\hline Article Info & Abstract \\
\hline $\begin{array}{l}\text { Received } \\
30 \text { Oktober } 2021\end{array}$ & $\begin{array}{l}\text { The purpose of this research and development is to describe the } \\
\text { process and results of the development of mathematics learning } \\
\text { resources in the form of interactive slideshows of Linear Equations of } \\
\text { Two Variables topic for junior high school students of 8th grade. This }\end{array}$ \\
\hline $\begin{array}{l}\text { Revised } \\
09 \text { November } 2021\end{array}$ & $\begin{array}{l}\text { development was carried out as an option of interactive learning } \\
\text { resources that are easy to be developed by teachers and to be operated } \\
\text { by students during the implementation of Distance Learning in this }\end{array}$ \\
\hline $\begin{array}{l}\text { Accepted } \\
11 \text { November } 2021\end{array}$ & $\begin{array}{l}\text { New Normal era. The development model used in this research is a } \\
\text { modification of the Plomp model, which includes the phases of initial } \\
\text { investigation, design, realization and test, evaluation, and revision. }\end{array}$ \\
\hline Keywords & $\begin{array}{l}\text { Even though the development process is simple, the results of the } \\
\text { validation of this learning resource indicate that the product is valid } \\
\text { with a percentage of } 85.8 \% \text { from the expert validation sheet, and is }\end{array}$ \\
\hline $\begin{array}{l}\text { Development, } \\
\text { Learning resources } \\
\text { Linear equation }\end{array}$ & $\begin{array}{l}\text { effective because } 100 \% \text { of students who are the subject using this } \\
\text { learning resource get a score of more than } 75 \text { and } 92 \% \text { of students } \\
\text { respond positively. }\end{array}$ \\
\hline
\end{tabular}

Copyright@2020 JIM, all rights reserved. Authors agree that this article remains permanently open access under the terms of the Creative Commons Attribution-ShareAlike 4.0 International License

How to Cite:

Lisarani, V. (2021). Pengembangan Sumber Belajar Matematika Berbentuk Slideshow Interaktif. Journal of Instructional Mathematics, 2(2), 90-98.

\section{PENDAHULUAN}

Semenjak kasus pertama Covid-19 di Indonesia yang terkonfirmasi diumumkan pada 2 Maret 2020 dan kematian yang pertama dilaporkan pada 11 Maret 2020 (Zhu dkk., 2020; Baskara, 2020), telah lebih dari 4.000.000 kasus positif yang dilaporkan di negara ini hingga artikel ini ditulis (Annisa, 2021). Situasi ini mendorong pemerintah Indonesia untuk mengeluarkan himbauan 'Work from Home' (WFH) per tanggal 15 Maret 2020 (Dewayani, 2020). Hal ini mempengaruhi banyak sektor, tidak terkecuali pendidikan, di mana guru wajib menyelenggarakan kelas dari jarak jauh yaitu dengan pengajaran daring.

Pelaksanaan pembelajaran daring (umumnya dikenal di Indonesia sebagai Pembelajaran Jarak Jauh/PJJ) yang mendadak jelas menimbulkan banyak kesulitan yang dihadapi tidak hanya oleh guru dan siswa, namun juga oleh orang tua. Kesulitan-kesulitan tersebut misalnya rendahnya literasi teknologi, infrastruktur digital yang tidak merata di Indonesia, serta ketimpangan sosial (Nugroho, 2020). Kementerian Pendidikan dan Kebudayaan RI juga menyatakan era 'The New Normal' bagi siswa di sekolah mulai Juli 2020 dimana PJJ dan/atau blended learning masih diterapkan di beberapa daerah yang terdampak COVID19 dengan tetap memperhatikan protokol kesehatan (Kridhangkara, 2020), dan kesulitan-kesulitan pembelajaran yang ditemui masih relatif sama. 
Dalam proses pembelajaran, bahan ajar sangatlah penting dalam mendukung pemahaman siswa (Amaliah \& Sudihartinih, 2019). Namun dengan masih berjalannya PJJ, ada keterbatasan sumber dan bahan ajar yang bisa diberikan guru kepada siswa. Sumber belajar berupa buku teks dirasa monoton dan tidak interaktif oleh siswa, sedangkan sumber belajar yang dibuat menggunakan aplikasi yang sifatnya advanced akan menyulitkan bagi guru untuk mengembangkannya serta memberatkan siswa yang tidak memiliki gawai yang memadai untuk mengoperasikannya. Di dalam penelitian pengembangan ini, peneliti hendak mengembangkan suatu sumber belajar interaktif sederhana menggunakan basis slideshow interaktif karena pengembangannya relatif mudah bagi guru serta pengoperasiannya relatif mudah bagi siswa. Bahan ajar yang disusun dalam bentuk slideshow telah digunakan oleh beberapa peneliti terdahulu dan terbukti mampu meningkatkan pemahaman siswa (Permatasari, 2014).

Berdasarkan pengamatan peneliti, kebanyakan guru memiliki laptop dan/atau akses komputer di sekolah yang pasti memiliki aplikasi pembuat slideshow (misalnya Microsoft Power Point), dan juga banyak siswa SMP yang cukup familiar dengan slideshow dan bisa mengoperasikannya dengan gawai mereka. Sedangkan terkait materi Persamaan Linear Dua Variabel (PLDV), materi ini adalah materi yang sangat erat hubungannya dengan kehidupan sehari-hari, dan merupakan materi prasyarat dari beberapa materi di tingkat yang lebih tinggi. Menanggapi latar belakang tersebut, pada penelitian dan pengembangan ini peneliti hendak mendeskripsikan proses dan hasil pengembangan sumber belajar berbentuk slideshow interaktif materi Persamaan Linear Dua Variabel bagi siswa SMP kelas VIII yang valid dan efektif, yang diharapkan bisa menjadi alternatif sumber belajar yang bisa digunakan selama PJJ di era New Normal.

\section{METODE PENELITIAN}

Model pengembangan yang digunakan adalah modifikasi dari model pengembangan Plomp. Langkah pengembangan yang dilakukan meliputi fase investigasi awal, desain, tes, evaluasi, dan revisi. Adapun kegiatan yang dilakukan pada investigasi awal meliputi analisis kompetensi yang harus dicapai siswa kelas VIII dan wawancara dengan salah satu guru pengajar matematika mengenai kemampuan dan respon siswa terhadap materi PLDV. Pada fase desain, disusun rancangan produk berupa sumber belajar berupa slideshow interaktif. Pada fase realisasi, rancangan produk yang merupakan hasil dari fase sebelumnya, direalisasikan menjadi produk. Pada fase tes, evaluasi, dan revisi, dilakukan kegiatan validasi produk dan uji coba produk hasil validasi. Validasi produk bertujuan untuk menilai kevalidan produk yang telah dikembangkan, sedangkan coba produk bertujuan untuk menilai keefektifan produk.

Validasi dilakukan oleh dua orang ahli, yaitu satu orang dosen dan satu orang guru matematika SMP. Tujuan proses validasi ini adalah untum mendapatkan data perbaikan, penilaian, pendapat, dan saran terhadap sumber belajar yang dikembangkan. Data tersebut yang akan menjadi acuan pelaksanan revisi produk sebelum diujicobakan kepada siswa. Kriteria atau kualifikasi validator disajikan dalam Tabel 1.

Uji coba produk dalam penelitian dan pengembangan ini dilakukan pada kelompok kecil, yaitu 6 siswa kelas VIII SMP yang berkemampuan heterogen. 
Instrumen pengumpulan data yang digunakan dalam penelitian dan pengembangan ini berupa lembar validasi, tes tertulis, dan angket respon siswa. Lembar validasi yang digunakan terdiri dari 2 bagian. Bagian pertama berisi penilaian skala 4 dengan bentuk checklist sedangkan bagian ke dua berupa lembar isian komentar dan saran. Komponen yang dinilai antara lain (1) keakuratan isi, (2) keakuratan konsep, (3) bahasa, (4) kelengkapan sajian, dan (5) kualitas tampilan. Tes tertulis berisi beberapa masalah yang terkait PLDV dan dikembangkan sesuai dengan indikator yang akan dicapai. Tes diberikan setelah siswa melakukan eksplorasi sumber belajar. Angket respon siswa digunakan untuk mengetahui respon siswa terhadap sumber belajar yang diujicobakan dan diberikan pada saat uji coba lapangan. Komponen-komponen produk yang dinilai adalah kemenarikan, kejelasan, kemudahan, serta kelogisan dan sistematika materi. Angket yang diberikan adalah angket tertutup dengan disediakan beberapa pilihan jawaban untuk dipilih siswa. Angket yang diberikan terdiri atas 2 bagian, yaitu pertanyaan tertutup dengan 4 pilihan jawaban (sangat setuju, setuju, kurang setuju, dan tidak setuju) serta lembar isian pesan dan kesan.

Tabel 1. Kualifikasi Validator Produk Pengembangan

\begin{tabular}{|c|c|}
\hline Kualifikasi untuk dosen & Kualifikasi untuk guru \\
\hline $\begin{array}{l}\text { - Dosen jurusan matematika yang ahli } \\
\text { dalam pengembangan dan materi } \\
\text { - Berpendidikan minimal S2 } \\
\text { matematika/pendidikan matematika } \\
\text { - Bukan merupakan anggota tim } \\
\text { penelitian pengembangan ini }\end{array}$ & $\begin{array}{l}\text { - Guru mata pelajaran matematika } \\
\text { SMP kelas VIII } \\
\text { - Telah menyelesaikan pendidikan } \\
\text { minimal S1 pada program studi } \\
\text { matematika/pendidikan matematika } \\
\text { - Berpengalaman mengajar setidaknya } \\
5 \text { tahun dan/atau telah lulus } \\
\text { sertifikasi guru }\end{array}$ \\
\hline
\end{tabular}

Teknik analisis data kevalidan dan keefektifan produk pada penelitian dan pengembangan ini memodifikasi dari Riduwan (2008) dan Hobri (2010). Modifikasi dilakukan pada skor yang diberikan, kriteria kevalidan, dan keefektifan. Pada Riduwan (2008) dan Hobri (2010) skor yang diberikan adalah dalam skala 5, sedangkan ada penelitian dan pengembangan ini, skor yang diberikan adalah dalam skala 4 untuk menghindari kecenderungan validator memilih skor yang berada di tengah. Dalam penelitian pengembangan ini, produk dinyatakan valid apabila telah melalui uji kevalidan oleh pakar matematika dan mendapatkan persentase kevalidan minimal $75 \%$. Pedoman penilaian kevalidan produk dapat dilihat pada Tabel 2, dan tingkat kevalidan produk dihitung dengan rumus berikut.

$$
P=\frac{\sum_{i=1}^{n} x_{i}}{n \times k} \times 100 \%
$$

Keterangan: $P=$ persentase pilihan, $\sum x_{i}=$ jumlah skor penilai seluruh validator, $n=$ banyaknya validator, $k=$ skor penilaian tertinggi. 
Tabel 2. Pedoman Penilaian Kevalidan Produk Pengembangan

\begin{tabular}{cc}
\hline Persentase & Kriteria Kevalidan \\
\hline $85-100$ & Sangat valid \\
$75-84$ & Valid \\
$65-74$ & Cukup valid \\
$55-64$ & Kurang valid \\
$0-54$ & Tidak valid \\
\hline
\end{tabular}

Produk yang dikembangkan dinyatakan efektif apabila dapat mendukung ketuntasan belajar serta mendapat respon positif dari siswa. Sehingga, pada analisis data keefektifan produk ini, dilakukan analisis terhadap angket respon siswa dan hasil belajar siswa. Hasil belajar siswa diuji dengan tes tertulis terkait materi Persamaan Linier Dua Variabel (PLDV) dengan indikator sebagai berikut: (1) membuat model matematika dari masalah nyata yang melibatkan PLDV, (2) menentukan selesaian dan bukan selesaian dari suatu PLDV, (3) menentukan apakah suatu ekspresi merupakan PLDV atau bukan PLDV, (4) membuat model matematika dari masalah nyata yang melibatkan SPLDV, (5) menentukan selesaian dan bukan selesaian dari suatu SPLDV, (6) menentukan apakah suatu sistem merupakan SPLDV atau bukan SPLDV, (7) menyelesaikan masalah nyata terkait SPLDV dengan metode grafik, (8) menyelesaikan masalah nyata terkait SPLDV dengan metode substitusi, (9) menyelesaikan masalah nyata terkait SPLDV dengan metode eliminasi, (10) menyelesaikan masalah nyata terkait SPLDV dengan metode campuran.

Berdasarkan Hobri (2010) produk dinyatakan efektif apabila minimal $80 \%$ siswa yang mengikuti pembelajaran mampu mencapai tingkat penguasaan materi minimal untuk mata pelajaran matematika, yaitu mencapai nilai 75 dari nilai maksimal 100, serta terdapat setidaknya $80 \%$ respon positif dari siswa.

\section{HASIL DAN PEMBAHASAN}

Hasil pada fase investigasi awal menunjukkan bahwa nilai dan respon siswa kelas VIII dalam materi PLDV masih kurang baik. Buku teks yang digunakan juga monoton sehingga motivasi belajar siswa rendah, terutama di kondisi Pembelajaran Jarak Jauh (PJJ). Dengan demikian diperlukan suatu sumber belajar yang relatif mudah pengembangan, pengoperasian, serta dan penyebarannya, sehingga penulis memutuskan untuk mengembangkan suatu sumber belajar berbentuk slideshow materi sistem persamaan linear dua variabel bagi siswa SMP kelas VIII.

Hasil pada fase desain berupa desain awal sumber belajar berbentuk slideshow. Sumber belajar ini antara lain memuat komponen-komponen: (1) judul yang ditentukan atas Kompetensi Dasar (KD), (2) petunjuk belajar, (3) kompetensi yang akan dicapai, (4) informasi pendukung, serta (5) tugas-tugas dan langkah kerja. Dalam pengembangan sumber belajar ini, peneliti memperhatikan daya tarik visual serta mengoptimalkan penggunaan fitur hyperlink yang akan memungkinkan siswa untuk tertarik berinteraksi dan juga memperoleh umpan balik langsung selama mengoperasikan sumber belajar ini, tidak hanya sekedar membaca isi slide yang membosankan. 


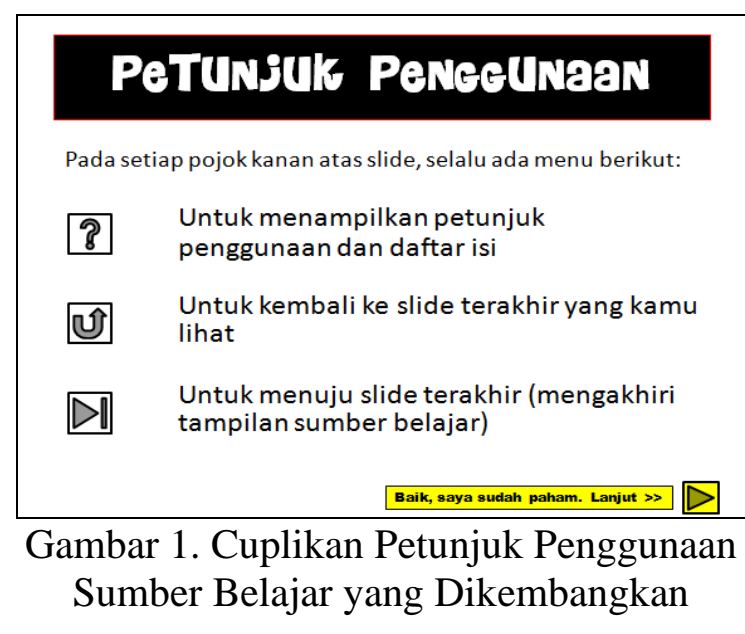

Hasil validasi produk oleh ahli disajikan dalam Tabel 3. Persentase penilaian untuk aspek kualitas isi mencapai $87,5 \%$ dengan kategori sangat valid. Hal ini menunjukkan bahwa materi dalam sumber belajar telah sesuai dengan indikator dan tujuan pembelajaran yang hendak dicapai. Sedangkan untuk aspek keakuratan konsep, persentase penilaian mencapai $87,5 \%$ dengan kategori sangat valid. Hal ini menunjukkan bahwa konsep yang termuat dalam materi disajikan sesuai dengan tingkat perkembangan siswa dan cakupan konsep dalam tiap satuan kegiatan dapat mewakili materi dalam sub pokok bahasan.

Tabel 3. Hasil Validasi Produk oleh Ahli

\begin{tabular}{lll}
\hline Aspek yang Dinilai & Persentase & Kriteria \\
\hline Kualitas isi & $87,5 \%$ & Sangat valid \\
Keakuratan Konsep & $87,5 \%$ & Sangat valid \\
Bahasa & $87,5 \%$ & Sangat valid \\
Kelengkapan Sajian & $85,4 \%$ & Sangat valid \\
Kualitas Tampilan & $84 \%$ & Valid \\
\hline
\end{tabular}

Hasil validasi bahasa yang digunakan dalam sumber belajar ini menunjukkan persentase $87,5 \%$, sehingga telah terkategori sangat valid. Sedangkan untuk aspek kelengkapan sajian, persentase penilaian mencapai 85,4\% dengan kategori sangat valid. Hal ini menunjukkan bahwa judul, petunjuk penggunaan, daftar isi, kompetensi dasar, materi prasyarat, dan tugas yang harus dilakukan siswa telah tercantum dengan jelas. Persentase penilaian aspek kualitas tampilan mencapai $84 \%$ dengan kategori valid.

Tabel 2. Hasil Tes Tertulis oleh Siswa

\begin{tabular}{lll}
\hline Nama Siswa (Inisial) & Nilai Siswa & Kategori \\
\hline NRA & 93 & sangat tinggi \\
RRFH & 97 & sangat tinggi \\
AOA & 88 & tinggi \\
AM & 88 & tinggi \\
SDS & 87 & tinggi \\
RDK & 85 & tinggi \\
Rata-rata & 89,7 & tinggi \\
\hline
\end{tabular}


Berdasarkan Tabel 2, seluruh siswa telah mendapatkan nilai lebih dari sama dengan 75. Secara keseluruhan, rata-rata nilai siswa adalah 89,7 dengan kategori tingkat pemahaman tinggi.

Produk dinyatakan valid karena telah memenuhi kriteria kevalidan yaitu memperoleh persentase penilaian lebih dari 75\%. Produk dinyatakan efektif karena terdapat minimal $80 \%$ siswa mendapatkan nilai lebih dari sama dengan 75 pada pengerjaan tes serta mendapat respon positif dari siswa, yaitu setidaknya rata-rata siswa menjawab $80 \%$ 'sangat setuju' atau 'setuju' pada angket respon siswa.

Tabel 3. Hasil Kegiatan Tes, Evaluasi, dan Revisi

\begin{tabular}{|c|c|c|c|}
\hline $\begin{array}{c}\text { Aspek yang } \\
\text { Dinilai }\end{array}$ & $\begin{array}{c}\text { Instrumen } \\
\text { Pengumpulan Data }\end{array}$ & Hasil & Keterangan \\
\hline $\begin{array}{l}\text { Kevalidan } \\
\text { Produk }\end{array}$ & $\begin{array}{l}\text { Lembar Validasi } \\
\text { Ahli }\end{array}$ & $\begin{array}{l}\text { Persentase } \\
\text { penilaian } 85,8 \%\end{array}$ & $\begin{array}{l}\text { Memenuhi kriteria } \\
\text { yang telah ditetapkan. }\end{array}$ \\
\hline \multirow[t]{2}{*}{$\begin{array}{l}\text { Keefektifan } \\
\text { Produk }\end{array}$} & Tes tertulis & $\begin{array}{l}100 \% \text { siswa } \\
\text { memperoleh skor } \\
\text { lebih dari } 75 \text {. }\end{array}$ & $\begin{array}{l}\text { Memenuhi kriteria } \\
\text { yang telah ditetapkan. }\end{array}$ \\
\hline & $\begin{array}{l}\text { Angket Respon } \\
\text { Siswa }\end{array}$ & $\begin{array}{l}\text { Terdapat } 92 \% \\
\text { respon positif dari } \\
\text { siswa }\end{array}$ & $\begin{array}{l}\text { Memenuhi kriteria } \\
\text { yang telah ditetapkan. }\end{array}$ \\
\hline
\end{tabular}

Dijelaskan oleh Munir (dalam Asmani, 2011: 111), pada era TIK (Teknologi Informasi dan Komunikasi) sekarang ini, paradigma pembelajaran telah bergeser dari pembelajaran tradisional menuju pembelajaran berbasis perkembangan teknologi. Pergeseran ini makin cepat terjadi dengan penerapan The New Normal di mana siswa dan guru harus melaksanakan PJJ. Meski demikian, cukup banyak kendala ditemui dalam pelaksanaan PJJ (Nugroho, 2020). Untuk menanggapi hal tersebut penelitian ini mengembangkan suatu sumber belajar interaktif yang mudah dikembangkan dan dioperasikan berbentuk slideshow. Slideshow relatif mudah penggunaan dan manipulasinya (Jubilee Enterprise, 2011). Dan dewasa ini tak jarang anak usia sekolah dasar telah mengenal dan mampu mengoperasikan perangkat lunak pembuat slideshow.

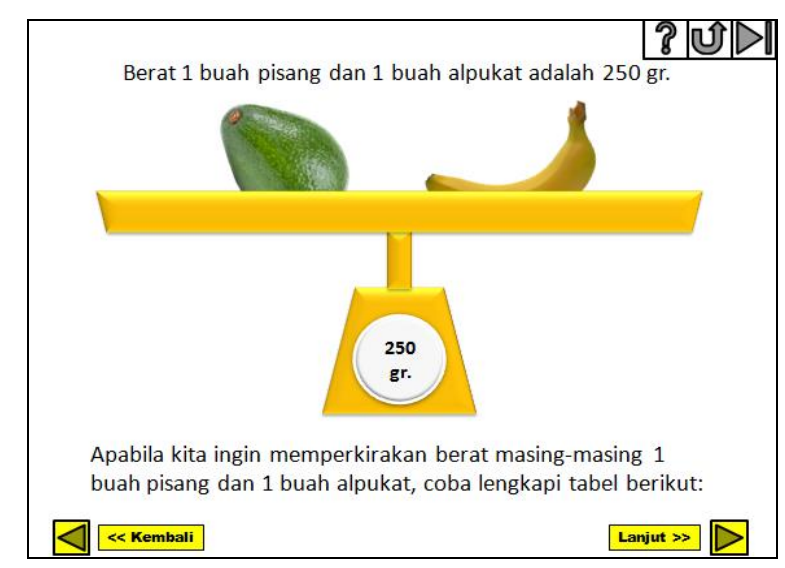

Gambar 2. Cuplikan Materi Inti Sumber Belajar yang Dikembangkan 
Produk yang dihasilkan dalam penelitian ini berupa sumber belajar berbentuk slideshow interaktif dalam bentuk file berformat *.ppt dengan spesifikasi sebagai berikut: (1) berisi tayangan slideshow yang menampilkan materi prasyarat, materi inti, contoh soal, latihan soal, dan pembahasan; (2) materi prasyarat adalah Operasi Aljabar, Persamaan Linear Satu Variabel (PLSV), dan Persamaan Garis Lurus; (3) materi inti mengacu pada SK/KD menurut silabus kurikulum yang berlaku; (4) contoh soal diharapkan akan memberikan siswa gambaran mengenai penyelesaian masalah nyata yang berkaitan dengan PLDV; (5) latihan soal dikemas dalam bentuk pilihan ganda. Ketika siswa meng-klik jawaban, akan muncul keterangan benar/salahnya jawaban mereka beserta pembahasan soal.

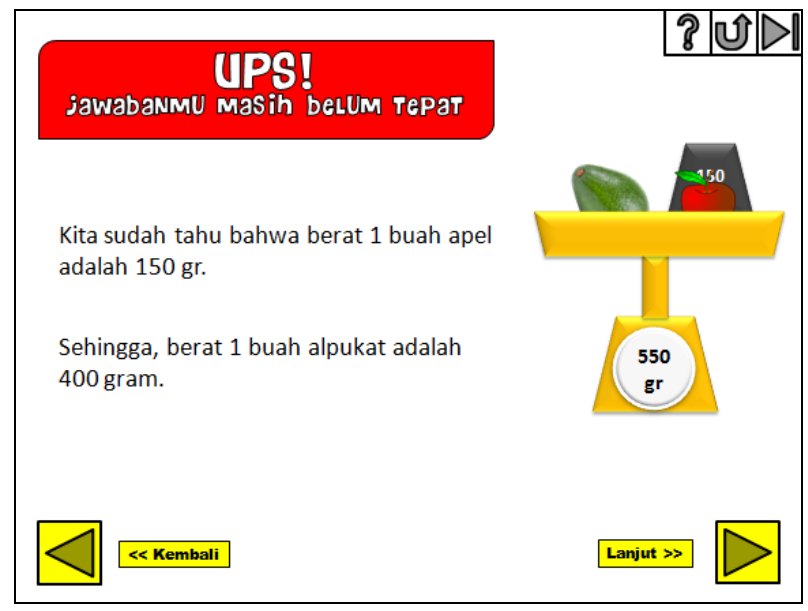

Gambar 3. Cuplikan Umpan Balik Jawaban yang Salah pada Sumber Belajar yang Dikembangkan

Kelebihan sumber belajar ini adalah mudahnya sumber belajar ini dibagikan untuk diakses siapapun dan kapanpun, mudahnya pengembangan sumber belajar lebih lanjut, fleksibilitas sumber belajar ini karena dapat digunakan dan diubah berdasarkan kebutuhan guru, banyaknya latihan soal dalam konteks nyata yang dikemas secara menarik dan runtut, serta dapat digunakan siswa secara mandiri karena tiap masalah yang dikerjakan oleh siswa akan langsung mendapatkan umpan balik (feedback) yang jelas. Sedangkan kekurangan sumber belajar ini adalah terbatasnya masalah-masalah yang ada di dalamnya hanya berbentuk pilihan ganda, sumber belajar hanya bisa dieksplorasi apabila terdapat gawai seperti laptop dan telepon genggam, keterbatasan uji coba keefektifan yang hanya dilakukan pada kelompok kecil, serta banyaknya slide yang membuat siswa merasa jenuh.

\section{KESIMPULAN}

Berdasarkan hasil validasi ahli, disimpulkan bahwa sumber belajar matematika berbentuk slideshow interaktif materi persamaan linier dua variabel ini valid dengan persentase $85,8 \%$. Sumber belajar ini antara lain memuat komponenkomponen: (1) judul yang ditentukan atas Kompetensi Dasar (KD), (2) petunjuk belajar, (3) kompetensi yang akan dicapai, (4) informasi pendukung, serta (5) tugas-tugas dan langkah kerja. Revisi produk yang dilakukan berdasarkan catatan validator sebelum dilakukan ujicoba lapangan antara lain menambahkan ilustrasi 
PLDV dan penyelesaian SPLDV dalam konteks nyata, memastikan tidak ada lebih dari satu pertanyaan dalam satu slide, menggunakan simbol matematika yang tepat, menggunakan kalimat yang efektif, serta menyajikan contoh dan bukan contoh PLDV dan SPLDV yang lebih variatif.

Berdasarkan hasil ujicoba lapangan, disimpulkan bahwa sumber belajar efektif. Hasil analisis angket respon siswa menunjukkan bahwa lebih dari $80 \%$ siswa memberikan respon positif, dan berdasarkan nilai uji kompetensi siswa lebih dari $80 \%$ siswa telah mencapai nilai lebih dari sama dengan 75 . Revisi yang dilakukan setelah uji coba lapangan adalah memperbaiki kesalahan penulisan yang ditemukan pada sumber belajar.

Saran yang dapat diajukan peneliti mengenai pemanfaatan dan pengembangan produk lebih lanjut adalah sebagai berikut: (1) Guru bisa memecah sumber belajar ini menjadi beberapa bagian menurut subbahasan agar siswa tidak merasa jenuh dalam mengeksplorasi, (2) Diharapkan untuk peneliti selanjutnya melakukan ujicoba pada kelompok yang lebih besar sehingga hasil uji keefektifan akan lebih akurat, (3) Diharapkan untuk peneliti selanjutnya mengembangkan sumber berbentuk slideshow interaktif untuk materi yang berbeda, (4) Diharapkan untuk peneliti selanjutnya mengembangkan sumber belajar berbasis dengan lebih memaksimalkan animation, slide transition, hyperlink, dan fitur-fitur lainnya

\section{REFERENSI}

Amaliah, I., \& Sudihartinih, E. (2019). Pengembangan Bahan Ajar Konsep Pecahan Berbantuan Multimedia Untuk Meningkatkan Kemampuan Pemahaman Matematis Siswa Di Sekolah Inklusi. Jurnal Pendidikan, 4(2), 610.

Annisa, D. (2021, September 18). Situasi Terkini Perkembangan Coronavirus Disease (COVID-19) 18 September 2021. Situasi Infeksi Emerging, Laporan Harian COVID-19. https://infeksiemerging.kemkes.go.id/situasi-infeksiemerging/situasi-terkini-perkembangan-coronavirus-disease-covid-19-18september-2021

Asmani, J.M. (2011). Tips Efektif Pemanfaatan Teknologi Informasi dan Komunikasi dalam Dunia Pendidikan. Penerbit Diva Press.

Baskara, B. (2020, April 18). Rangkaian Peristiwa Pertama Covid-19. Kompas. https://bebas.kompas.id/baca/riset/2020/04/18/rangkaian-peristiwa-pertamacovid-19/

Dewayani, T. (2020, Maret 31). Bekerja dari Rumah (Work from Home) dari Sudut Pandang Unit Kepatuhan Internal. Kementerian Keuangan Republik Indonesia. https://www.djkn.kemenkeu.go.id/artikel/baca/13014/Bekerja-dariRumah-Work-From-Home-Dari-Sudut-Pandang-Unit-Kepatuhan-Internal.html

Hobri, H. (2010). Metodologi Penelitian Pengembangan (Aplikasi pada Penelitian Pendidikan Matematika). Pena Salsabila.

Jubilee Enterprise. (2011). Desain Slide Presentasi: ketika PowerPoint Bertemu dengan Photoshop CSS. Elex Media Komputindo.

Kridhangkara, W. (2020, Mei 28). Skenario Belajar di Era New Normal: Siswa Sehari Masuk - Sehari Libur. SoloPos.com. https://www.solopos.com/skenario-belajar-di-era-new-normal-siswa-seharimasuk-sehari-libur-1062987 
Nugroho, T. T. (2020, Mei 14). Pembelajaran Jarak Jauh di Masa Pandemi. Tempo. $\quad$ https://kolom.tempo.co/read/1342106/pembelajaran-jarak-jauh-dimasa-pandemi

Permatasari, A. A. (2014). Pengaruh penggunaan multimedia powerpoint terhadap peningkatan kemampuan menulis cerita pendek pada pembelajaran bahasa Indonesia. PEDAGOGIA Jurnal Ilmu Pendidikan, 12(1), 19-23. https://doi.org/10.17509/pedagogia.v12i1.3297

Riduwan. (2008). Metode dan Teknik Menulis Tesis. Alfabeta.

Zhu, N., Zhang, D., Wang, W., Li, X., Yang, B., Song, J., ... \& Tan, W. (2020). A novel coronavirus from patients with pneumonia in China, 2019. New England journal of medicine. https://doi.org/10.1056/nejmoa2001017 